International Journal of Instruction e-ISSN: 1308-1470 • www.e-iji.net

Article submission code: 20210126112648

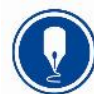

October $2021 \bullet$ Vol.14, No.4

p-ISSN: 1694-609X

pp. $985-996$

Received: 26/01/2021

Revision: 13/05/2021
Accepted: 09/06/2021

OnlineFirst: 10/09/2021

\title{
Effects of Self-Regulated Strategy Development Strategy on Story Writing among Students with Learning Disabilities
}

\section{Sahar Zedan Zaien}

Assoc. Prof., Department of Special Education, College of Art \& Education, University of Tabouk, Saudi Arabia, sah_zed@hotmail.com

The aim was to explore the effectiveness of a SRSD- based training program on story writing among second-year middle-school learning disabled students in Saudi Arabia. Participants were 50 students from a middle school in KSA. Participants were selected from two intact classes, which were assigned as control and experimental groups, with each group having 25 participants. A two-group prepost design was used to compare story writing of participants. In the preintervention phase, students individually wrote one story that was evaluated by two teachers of English. In the pre-intervention phase, students individually wrote one story that two English language teachers evaluated. ANCOVA and t-test analyses were used for analysing data .Findings indicated the effectiveness of the program employed in improving story writing among the target students. Accordingly, the study advocated a self-regulated strategy development-based training program for improving story writing among $2^{\text {nd }}$ year-middle-school learning disabled students in KSA.

Keywords: self-regulated strategy development, story writing, writing, learning, students

\section{INTRODUCTION}

Recent literature has shown the positive impact of supporting writing instruction with self-regulated strategy development strategy for students who found writing to be difficult matter(Bewley,2020; Sean, Lowrey, Bruce \& Rowland,2020). Researchers agree that writing is a complex activity, and that learning to write is potentially even more complicated (Harris, Graham, Mason, \& Friedlander, 2008). Harris and Graham (2009) claimed that approximately $85 \%$ of the world's population now writes. Through writing, which is said to be a flexible means that people can use to achieve various goals (Graham, 2006). Writing offers people the chance to communicate with each other (Steve \& Dolores, 2007). People may use writing as a powerful medium for convincing others of their thoughts and ideas. People sometimes use writing to show their identity or who they are, fight against their sense of loneliness and, record, and document their experiences. One can benefit from writing about his/her feelings, either psychologically or physiologically (Steve \& Dolores, 2007). In Saudi Arabia, students face challenges and difficulties in mastering writing skills, which, due to their teachers' teaching

Citation: Zaien, S. Z. (2021). Effects of self-regulated strategy development strategy on story writing among students with learning disabilities. International Journal of Instruction, 14(4), 985-996. https://doi.org/10.29333/iji.2021.14456a 
methods, depend greatly on rote learning. Accordingly, students rely on the modelled written texts that their teachers provide. This, in turn, does not give them the chance to write independently (Barzanji, 2016).

Unfortunately, the majority of EFL teachers (Maggie, 2013), when asked, reported that they were not prepared adequately during their college stage and pre-service period in writing instruction. They rarely implemented evidence-based practices (EBPs). A successful strategy, such as SRSD, might give them a hand. Since 1985, many studies have employed the SRSD model of instruction in the area of writing. These studies involved many types of students from elementary grades through secondary or high school (Graham \& Harris, 2009). The findings from a meta-analysis of true- and quasiexperimental design studies (Graham \& Harris, 2009) indicated that SRSD had had a significant and substantial impact compared to any other instructional approaches in writing, as the use of SRSD approach has developed writing strategies for various types of writing including personal narratives, story writing, persuasive essays, report writing, expository essays, and state writing tests.

Harris and Graham (2009) confirmed that using SRSD has resulted in significant and meaningful improvements in children's development of planning and revising strategies, including brainstorming, self-monitoring, reading for information and semantic webbing, generating and organizing writing content, advanced planning and dictation, revising with peers, and revising for both substance and mechanics.

\section{Problem Statement}

Writing achievement is an indispensable component of standardized testing as well as being a basic aid for curriculum developers in different educational stages. It is the primary way through which students can demonstrate their knowledge. Moreover, researchers have used writing achievement as the most common means when they evaluate their students' performance in the classroom assessments. Writing is regarded as a fundamental skill. People can use it in their professional, social, community, and civic engagements. It also can be a critical and crucial skill in our world today. Nevertheless, most students do not develop the writing proficiency needed to showcase what they know (Santangelo, Harris, \& Graham, 2016). Writing, as defined by the National Center for Education Statistics (NCES), is "a complex, multifaceted, and purposeful act of communication accomplished in a variety of environments, under various constraints of time, and with a variety of language resources and technological tools" (NCES, 2012, p. 4). A proficient writer, as explained by NCES (NCES is one who clearly demonstrates "the ability to accomplish the communicative purpose of their writing" (NCES, p. 1).

When investigating Saudi students' perceptions of their English writing difficulties, Maggie (2013) reported that part of those difficulties stem from the fact that Saudi schools do not emphasize writing skills in students' first language, Arabic. The teaching of Arabic composition in Saudi schools "does not emphasize strategies that skilled writers commonly employ when writing, such as prewriting, planning, and supporting their ideas by example" (52). In intermediate and high schools, Saudi students are introduced to a guided composition in the form of pre-constructed models of short 
pieces of writing, which they are required to memorize for tests. Memorizing a limited number of pre-constructed, isolated pieces deprives students of experience in some of the major requirements needed for writing.

The challenges Saudi students face in literacy are that their performance does not meet educational policymakers' expectations. These challenges align with what Fageeh (2003) said, "Students at every level possess a low level of English proficiency and have not achieved the goals of English instruction" (p. 4).

It was claimed that Saudi students considered writing in English one of their most difficult educational experiences (Donna, 2010). Abdel Latif (2008, as cited by Maggie, 2013) shows that the most frequent rhetorical problems that Arab Gulf region students face occur in writing argumentative essays, and relate to development, support, organization, and persuasiveness. Writing is of great importance, however, too many students do not learn to write well enough to be eligible for the job market.

\section{Significance}

SRSD has had the strongest impact of any strategies instruction approach in writing (Graham \& Perrin, 2007). Further research is needed to study the effects of SRSD on story writing that have been proven to be effective (Graham, MacArthur, \& Fitzgerald, 2007; Graham \& Perin, 2007; Peterson-Karlan \& Parette, 2007; Mourad, 2009) among second year- middle school learning disabled students in Saudi Arabia. This study examines if self-regulated strategy development based training program, will improve story writing among fifth year- elementary school learning disabled students. This will help students do well in their writing performance. Moreover, the program will help policy makers put SRSD into consideration when thinking of the best methods of teaching writing skills.

\section{Purpose}

This study investigated the effectiveness of SRSD on story writing among second-yearmiddle-school learning disabled students in Saudi Arabia.

\section{Literature Review}

\section{The writing process}

In writing , as a process of communicating with others , the writer puts his/her ideas and thoughts in written forms in order to be conveyed to his/her readers. It tells us how the writer thinks, and how he/she discovers, organizes, and communicates his/her thoughts to the reader. Moreover, writing is a means of human communication that represents a language through certain signs and symbols. Written symbols can represent spoken language by creating a transcript of speech that can be stored for future reference or sent elsewhere. In other words, writing is not a language, but a tool used to make languages readable (Kuni, 2018). As viewed by Harmer (2004), writing is a process as having four fundamental steps. The first is: planning, which - though challenging, is one of the more effective writing process features (Abderraouf, 2016). The second is drafting. Writers produce a draft of their topic that is a subject of amendment afterwards, with the aim of gathering much information, ideas and arguments that they (writers) will use later on in 
their topic writing" (Abderraouf, 2016). The third is editing. In this step, the writer revises what has been written so far, emphasizing the many writing elements. Editing is the stage through which writers reflect on what has been done in the previous stages. Accordingly, they plan for the next step, which is publishing. This is the refined, errorsfree copy the writer delivers to a specialist to evaluate (Abderraouf, 2016; Donohue, 2009).

Effective writing instructional strategy: Self-Regulated Strategy Development (SRSD)

SRSD is a flexible instructional model that teachers and instructors used to teach students to be self-regulated writers. Teachers use it as a strategy that helps students in their quest to be self-regulated learners (Harris et al., 2008).

Through self-regulated strategy development (SRSD), teachers explicitly teach students certain concrete strategies that support them in improving their writing and other academic skills. These strategies may vary depending on the area of the content studied and the learner's age and needs. For instance, teachers might help students with a specific strategy that allows them to brainstorm ideas when they plan to write a story (Harris, et al., 2008). SRSD includes six stages (Harris and Graham, 2017).

1. Develop Background Knowledge: Students are taught whatever skills or knowledge are needed to use and implement the strategy successfully.

2. Discuss It: Students examine their current performance in writing, and together, with their classmates or teachers, they discuss how beneficial the new strategy is , as well as what purpose this strategy has.

3. Model It: The teacher models how the strategy can be used and presents and models self-regulation techniques.

4. Memorize It: Students now are in a position to memorize different steps of the new strategy.

5. Support It: Teachers' support and scaffolding fade gradually, and students practice the use of strategy somewhat independently.

6. Independent Performance: Students practice using strategy in a dependent way, without any help, support, or scaffolding from their teachers.

When being instructed, students become responsible for implementing the strategy as it gradually transferred to them, until they are able to perform the tasks adequately with no scaffolding (Harris and Graham, 2009). Worth noting, these stages are flexible in that they provide general guidelines for teaching writing strategies and can be used in a different order. They can be used individually or collectively, or modified if the needs of the students and the teachers are to be met (Fahim \& Rajabi, 2015).

\section{METHOD}

\section{Participants and Setting}

Fifty students from a middle school in Tabouk were recruited. Students who demonstrated low achievement scores on a cognitive reading comprehension test (standardized test Mourad, 2015) (i.e., at least 1.5 [SD] below their same age people (APA, 2013, p. 70; Mourad, 2018, p. 109), though their normal levels of intellectual 
functioning (Mourad, 2012; Mourad \& Amaal, 2013; Mourad\& Beata,2019;El Banna, 2019; Hesham \& Rasha, 2014;Nassar,2019), the absence of any neurological or motor disorders (Al Said, 2014; Mohammed, 2014, Omema, 2015) were included. So 50 students from the school mentioned above were selected. They were all in the $2^{\text {nd }}$ year. They were aged from 13-14 years $(\mathrm{M}=13.6, \mathrm{SD}=1.02)$.

Students of the two groups were matched on age, IQ, and Written Performance. Table 1. shows the results of this procedure. As shown, $t-$ values did not reach significance level. This indicated that the two groups did not differ in age, IQ, and Written Performance(pre-test).

Table 1

Matching students in both groups on age (by month), IQ, and written performance (pre-test).

\begin{tabular}{|c|c|c|c|c|c|c|}
\hline Variable & Group & $\mathrm{N}$ & M & Sta.D. & $\mathrm{T}$ & Sig. \\
\hline \multirow[t]{2}{*}{ Age } & Exp & 25 & 142 & 1.01 & \multirow[t]{2}{*}{.012} & \multirow[t]{2}{*}{ Not sig. } \\
\hline & Cont. & 25 & 141 & 1.13 & & \\
\hline \multirow[t]{2}{*}{ IQ } & Exp & 25 & 111.72 & 1.08 & \multirow[t]{2}{*}{.010} & \multirow[t]{2}{*}{ Not sig. } \\
\hline & Cont. & 25 & 111.86 & 1.05 & & \\
\hline \multirow{2}{*}{$\begin{array}{l}\text { Written } \\
\text { Expr. }\end{array}$} & Exp & 25 & 23.96 & 1.89 & \multirow[t]{2}{*}{.541} & \multirow[t]{2}{*}{ Not sig. } \\
\hline & Cont. & 25 & 24.36 & 1.90 & & \\
\hline
\end{tabular}

\section{Materials}

Instructional Materials

Instruction for the current study took place during students' English Language lessons period for 50 minutes, 3-4 times per week. The intervention for the present study was the $\mathrm{W}-\mathrm{W}-\mathrm{W}$, What $=2$, How $=2$, story writing strategy, and self-regulation procedures. All students in the experimental group utilized the strategy steps to write stories that were longer, contained essential elements, and were of overall better quality.

Teacher's Assessment Scale for the Student's Written Performance

This scale was developed particularly for this study. The aim was to measure the writing skills of the following: formation of ideas, their organization, depth, detail, use of vocabulary, syntax, spelling, capitalization, punctuation, and handwriting. The overall item pool was generated with the help of a literature review. The scale consisted of 10 elements of assessment, under each component 5 choices existed through which the teacher evaluated the quality of the written performance of the student. The score ranges from (1-5), the total score on the scale (10 - 50). Cronbach's alpha coefficient for the whole scale was 0.84 and for subscales ranged from 0.79 to 0.82 . Convergent validation was established ( Teacher's Assessment Scale for the Student's Written Performance and the Writing Skills Test "Mourad, 2009"). Results indicated that both scales had a significant and positive correlation with each other $(\mathrm{r}=.78, \mathrm{p}<.001)$.

\section{Procedures}

\section{Pre-Intervention Testing}

All the fifty students wrote one story each. Two English teachers evaluated each story according to the criteria mentioned in the writing test. The inter-rater reliability of the 
test was calculated before the administration of the experiment. The percent agreement $=100 \%$. The data was reported for the students who completed the study.

General Instruction: SRSD based training program: During the first stage of the instruction, the researcher introduced herself as the writing researcher. She determined with students' background knowledge about story writing by discussing "what makes a story good." She also discussed with students what they do when they write. Next, she introduced the strategy POW, where she used a chart with the mnemonic POW to discuss each part. Students practiced, discussed goals for learning POW, and then discussed the parts of a good story. Next, the researcher introduced the strategy, W-WW, to help her students remember the seven parts of an English story.

Then, during "discuss it," students reviewed different parts of POW. The researcher explained how important is the self-monitoring in the writing process and introduced graphing that helps students monitor themselves while writing. The notion of and memorizing the mnemonics POW..

The researcher emphasized collaboration. Students were encouraged to help the researcher put their ideas into note form. The researcher discussed and modeled the value and use of self-statements. Specifically, problem definition statements, coping statements, self-reinforcement, planning, and self-evaluation statements were modeled as the researcher used POW and $\mathrm{W}-\mathrm{W}-\mathrm{W}$, What $=2$, How $=2$ to plan a story. The researcher modeled how to write a story using POW, W-W-W, What $=2$, How $=2$, and self-statements from start to finish.

Next, memorized the mnemonics. The researcher added additional practice until students were able to remember all the parts and their significance. The researcher began generalization training, which was referred to as "transfer." Transfer was defined as using POW and W-W-W, What $=2$, How $=2$ with other kinds of writing such as paragraph writing, letter writing, e-mail writing. etc., in places other than the instructional setting.

Then, students used the strategy more independently. The researcher continued to support using the strategy by prompting students to utilize their self-statements and mnemonics; however, support was decreased as the students become more proficient at using the strategy.

Last, students used the strategies they have learned in the previous stages to write a story on their own. The goal was for each participant to independently write a story.

The researcher had a notebook that contained detailed directions for implementing all activities and lessons. She had a checklist for each lesson. As she taught a lesson, she checked each step as it was completed. Students received three training sessions a week, lasting between 40 to $45 \mathrm{~min}$. Instruction took place in the regular classroom to naturalize the situation.

\section{Design}

A two-group pre-post design was used to compare story writing before and after the intervention. In the pre-intervention phase, students individually wrote one story that . 


\section{FINDINS}

Table 2 shows ANCOVA analysis data for the differences in post-test mean scores between experimental and control groups in the Teacher's Assessment Scale for the Student's Written Performance. A significant difference was found between the two groups on post-intervention scores on the Teacher's Assessment Scale for the Student's Written Performance. The table shows that the (F) value was (658.055). This value was significant at the level $(0.01, \mathrm{p}<0,01)$ in favor of the treatment condition.

Table 2

ANCOVA analysis : Teacher's assessment scale for the student's written performance

\begin{tabular}{llllll}
\hline Source & Type 111 Sum of squares & df & Mean square & F & Sig. \\
\hline Pre & 7.334 & 1 & 7.334 & & \\
Group & 3448,012 & 1 & 3448,012 & 658.055 & 0.01 \\
Error & 246.266 & 47 & 5.240 & & \\
Total & 4108.020 & 49 & & & \\
\hline
\end{tabular}

Table 3 shows t-test results for the differences in post-test mean scores between experimental and control groups in the Teacher's Assessment Scale for the Student's Written Performance. The table shows that $(\mathrm{t})$ vale was (27.010). This value is significant at the level $(0.01, \mathrm{p}<0.01)$ in favor of the treatment condition. The table also shows differences in post-test mean scores between experimental and control groups in the Teacher's Assessment Scale for the Student's Written Performance in favor of the experimental group.

Table 3

T-test results : teacher's assessment scale for the student's written performance

\begin{tabular}{llllll}
\hline Group & $\mathrm{N}$ & Mean & Std. deviation & $\mathrm{t}$ & Sig. \\
\hline Experimental & 25 & 41.92 & 2.19 & 27.010 & 0.01 \\
Control & 25 & 24.36 & 2.39 & & \\
\hline
\end{tabular}

Concerning the differences between pre- post-test scores of the experimental group on the Teacher's Assessment Scale for the Student's Written Performance, t-test results were conducted.

Table 4

T-test test results for the differences between pre-post- test scores of the experimental group on teacher's assessment scale for the student's written performance

\begin{tabular}{llllll}
\hline & N & Mean & Std. deviation & t & Sig. \\
\hline Pre & 25 & 23.96 & 2.19 & 31.046 & 0.01 \\
Post & 25 & 41.92 & 1.88 & & \\
\hline
\end{tabular}

Table 3 shows t-test results for the differences between pre-post- test scores of the experimental group on the Teacher's Assessment Scale for the Student's Written 
Performance. The table shows that (t) vale was (31.046). This value is significant at the level $(0.01, \mathrm{p}<0.01)$ in favor of post-testing.

\section{DISCUSSION AND CONCLUSIONS}

The aim was to investigate the effectiveness of SRSD on story writing among $2^{\text {nd }}$ year middle school learning disabled students in KSA. The current study results indicated that SRSD in writing is an effective intervention for $2^{\text {nd }}$ middle school learning disabled students in KSA. All students in the experimental group could write longer stories that were characterized by having more essential elements. They could achieved academic gains after the training program. The genre-specific intervention applied in this study taught students strategies for planning and writing a story in English. Students were also taught the knowledge, skills, and self-regulated procedures needed to initiate and control story writing effectively. I anticipated that such instruction would have a meaningful impact on students' overall writing performance. I also expected a salutary effect on students' reported use of self-regulated strategies for general school writing tasks because SRSD instruction includes the explicit teaching of several self-regulatory strategies(ElAdl, and Polpol,2020) that may be transferred to other uninstructed genres (Harris \& Graham, 2017).

As predicted, the researcher implemented whole-class SRSD instruction enhanced the story writing performance of this study's second-year middle-school learning disabled participants. Story written by students evidenced greater improvement than those of students in the control condition immediately after instruction on overall writing quality. This helped them plan and monitor their learning activities. They could control the general conditions associated with learning, such as time management and management of the learning environment (Al Said, 2014; ElAdl, 2020; Mostafa, 2014; Mourad, 2015; Muhassin, Annisa\& Hidayati,2021; Sari, Sumar, Utomo\& Astina,2021). These results replicate findings from similar studies carried out in the framework of the SRSD model point to the improved writing performance of participants (Graham \& Harris, 2003), fostered writing knowledge (Graham, Harris, \& Mason, 2005), and their motivation (Graham et al., 2005).

To conclude, implementing whole-class SRSD instruction enhanced the story writing performance of the target students. Story written by students evidenced greater improvement than those of students in the control condition immediately after instruction on overall writing quality.

\section{IMPLICATIONS}

Graham and Harris (2009) described a theoretical framework in which writing was developed through four major areas: 1) motivation, 2) strategic behavior, 3) skills, and 4) knowledge within the SRSD instructional strategies method. This study examined the effectiveness of a self-regulated strategy development based training program on story writing among EFL third grade students in Saudi Arabia. The results indicated that SRSD positively affected story writing among students from the 110th secondary school for girls in Jeddah. Self-Regulated Strategy Development (SRSD) is an evidence-based practice in writing and has previously been studied across several specific writing genres, such as narrative, opinion, expository, and story writing (Graham \& Perin, 
2007). The findings from the current study indicated that all students in this study (the experimental group) increased their overall story writing. This result supports the research from previous studies examining SRSD, which demonstrated increases in writing performance (Graham, Harris, \& Mason, 2005; Mason \& Shriner, 2008).

\section{Implications for Teaching}

The current study results indicate promise for academic interventions for learning disabled students in Saudi Arabia. Notably, the participants in the experimental group of the present study demonstrated success using SRSD to write stories that were longer, contained more essential elements, and were of overall better quality. These results were achieved through intense instruction.

\section{RECOMMENDATIONS}

SRSD in writing is an evidence-based practice (Graham \& Perin, 2007). It is effective in increasing the overall writing quality for a variety of students. Teachers and researchers should understand that providing cognitive strategy instruction and making writing more explicit is complex. Teachers need to ensure that they utilize the research-based materials (Harris et al., 2008) to ensure that they implement the SRSD in writing strategy correctly and with fidelity. Further research is still required to explore the potential benefits of SRSD in writing. Such research may include large scale studies and further exploration of the exact influence of student attendance, researcher training, classroom conditions, and treatment duration and intensity. Pedagogical knowledge needs to be evidence-based.

\section{REFERENCES}

Al Said, A. (2014). The effect of metacognitive strategy training on student mathematical problem solving process and contemplative thinking skills in primary school children with learning disabilities. Psycho-Educational Research Reviews, 3(2), $3-11$.

American Psychiatric Association. (2013). Diagnostic and statistical manual of mental disorders (5th ed.). Online version.

Barzanji, A. (2016). Identifying the most common errors in Saudi university students ' writing: does the prompt matter? [Master's thesis, University of Central Florida, Orlando, Florida]. Retrieved December 27, 2020, from https://stars.library.ucf.edu/cgi/viewcontent.cgi?article= 5922\&context=etd

Bewley, S.(2020).The effects of self-regulated strategy development instruction on argument writing skills of adolescents with mild disabilities. Electronic Theses and Dissertations

Donohue, L. (2009). The write beginning. Markham, ON.: Pembroke Publishers.

ElAdl, A. (2020). Effectiveness of a Brain-Based Learning Theory in Developing Mathematical Skills and Scientific Thinking Among Students With Learning Disabilities in Oman". Psycho-Educational Research Reviews, 9(2), 67-74.

ElAdl, A \& Polpol, Y. (2020). The Effect of Self-Regulated Learning Strategies on Developing Creative Problem Solving and Academic Self-Efficacy Among 
Intellectually Superior High School Students. Psycho-Educational Research Reviews 9 (1):97-106. https://www.journals.lapub.co.uk/index.php/perr/article/view/1390.

El Banna, A. (2019). The Effects of Multiple Intelligences Training Program on Improving Reading Comprehension Skills of Reading of the Disabled Primary Six Students. Psycho-Educational Research Reviews, 8(1), 64-69.

Fageeh, A. I. (2003). Saudi college students' beliefs regarding their English writing difficulties [Doctoral dissertation, Indiana University of Pennsylvania].

Fahim, M., \& Rajabi, S. (2015). Applying self-regulated strategy development model of instruction to teach writing skill: Effects on writing performance and writing motivation of EFL learners. International Journal of Research Studies in Education, 4(2), 29-42

Graham, S. (2006). Writing. In P. Alexander \& P. Wiine (Eds.), Handbook of educational psychology (pp. 457-477). Erlbaum.

Graham, S., \& Harris, K. R. (2003). Students with learning disabilities and the process of writing: A meta-analysis of SRSD studies. In L. Swanson, K. Harris, \& S. Graham (Eds.), Handbook of learning disabilities (pp. 383-402). The Guilford Press.

Graham, S., \& Harris, K. R. (2009). Evidence-based writing practices: Drawing recommendations from multiple sources. British Journal of Educational Psychology Monograph Series, II(6), 97-114.

Graham, S., \& Perin, D. (2007). Writing next: Effective strategies to improve writing of adolescents in middle and high school- $\mathrm{A}$ report to Carnegie Corporation of New York. Washington, DC: Alliance for Excellence in Education. Retrieved December 27, 2020,

from https://eric.ed.gov/?redir=http $\% 3 \mathrm{a} \% 2 \mathrm{f} \% 2 \mathrm{fwww}$.all4ed.org\%2ffiles\%2fWritingNext.pdf

Graham, S., \& Perin, D. (2007). A meta-analysis of writing instruction for adolescent students. Journal of Educational Psychology, 99(3), 445-476. doi: 10.1037/00220663.99.3.445

Graham, S., Harris, K.R., \& Mason, L. H. (2005). Improving the writing performance knowledge, and self-efficacy of struggling young writers: The effects of self-regulated strategy development. Contemporary Educational Psychology, 30(2), 207-241. https://doi.org/10.1016/j.cedpsych. 2004.08.001

Graham, S., MacArthur, C. A., \& Fitzgerald, J. (2007). Introduction: Best practices in writing instruction now. In S. Graham, C.A. MacArthur, \& J. Fitzgerald (Eds.), Handbook of writing research (pp. 1-7). The Guilford Press.

Harris, K. R., \& Graham, S. (2009). Self-regulated strategy development in writing: Premises, evolution, and the future. BJEP Monograph Series II: No. 6. Teaching and Learning Writing (pp. 113-135). British Psychological Society. https://doi.org/10.1348/978185409X422542

Harris, K. R., \& Graham, S. (2017). Self-Regulated Strategy Development: Theoretical bases, critical instructional elements, and future research. In R.F. Redondo, K. Harris, \& M. Braaksma (Eds.), Design principles for teaching effective writing (pp. 119-151). Brill. https://doi.org/10.1163/9789004270480_007 
Harris, K. R., Graham, S., Mason, L., \& Friedlander, B. (2008). Powerful writing strategies for all students. Paul H. Brookes Publishing Co.

Harris, K. R., Lane, K. L., Graham, S., Driscoll, S. A., Sandmel, K., Brindle, M., \& Schatschneider, C. (2012). Practice-based professional development for self-regulated strategies development in writing a randomized controlled study. Journal of Researcher Education, 63(2), 103-119. Retrieved from https://eric.ed.gov/?id=EJ955876

Hesham H., \& Rasha, M. (2014). Effectiveness of differentiated instruction on achievement in mathematics of middle school students with learning disabilities. Psycho-Educational Research Reviews, 3(1), 29-34.

Hikmah, K. H. (2018). Teaching writing to EFL learners: An investigation of challenges Confronted by Indonesian researchers. LANGKAWI Journal, 4(1), 21-31

Mason, L. H., \& Shriner, J. G. (2008). Self-regulated strategy development instruction for writing an opinion essay: Effects for six students with emotional/behavior disorders. Reading and Writing, 21(1), 71-93. https://doi.org/10.1007/s11145-007-9065-y

Mohammed, A. (2014). The effect of differentiating instruction using multiple intelligences on improving reading comprehension of 5th Graders with learning disabilities. Psycho- Educational Research Reviews, 3(2), 12-20.

Mostafa, A. (2014). Effects of metacognition instruction on self efficacy of primary school children with learning disabilities. Psycho- Educational Research Reviews, 5(5), 44-50.

Mourad, A. E. (2018). Issues related to identification of children with specific learning disorders (SLDs): Insights into DSM-5. Psycho- Educational Research Reviews, 7(1), 106-111.

Mourad, A.E. (2009). The effectiveness of a program based on self-regulated strategy development on the writing skills of writing-disabled secondary school students. Electronic Journal of Research in Educational Psychology, 7(1), 5-24. Retrieved December 27, 2020, from http://repositorio.ual.es/bitstream/handle/10835/529/Art_17_300.pdf?sequence=1

Mourad, A.E. (2012). The effects of advance graphic organizers strategy intervention on academic achievement, self efficacy, and motivation to learn social studies in learning disabled second year prep students. Psycho- Educational Research Reviews, 1(1),13-26.

Mourad, A.E. (2015). The effectiveness of a self regulated learning-based training program on improving cognitive and metacognitive EFL reading comprehension of 9th graders with reading disabilities. Psycho- Educational Research Reviews, 4(3), 49-59.

Mourad A. (2018). Issues Related to identification of children with specific learning disorders (SLDs): Insights into DSM-5. Psycho- Educational Research Reviews, 7(1), 106-112.

Mourad, A. E., \& Amaal, M. (2013). The effects of differentiated instruction by integrating multiple intelligences and learning styles on solving problems, achievement in, and attitudes towards math in six graders with learning disabilities in cooperative groups. Psycho- Educational Research Reviews, 2(2), 31-43. 
Mourad, A. E., \& Beata Borowska-Beszta. (2019). Disability in the Arab World: A Comparative Analysis Within Culture. Psycho-Educational Research Reviews, 8(2), 2947.

Muhassin,M., Annisa,J.\& Hidayati,D.(2021). The Impact of Fix Up Strategy on Indonesian EFL Learners' Reading Comprehension. International Journal of Instruction, 14(2), 253-270

Nassar, E. (2019). The effects of brain-based learning approach on study habits and test anxiety among first-year preparatory school students with learning disabilities. PsychoEducational Research Reviews, 8(1), 70-75.

National Center for Education Statistics [NCES]. (2012). The nation's report card: Writing 2011 national assessment of educational progress at grades 8 and 12 .

Omema, M. (2015). The effect of reciprocal teaching intervention strategy on reading comprehension skills of 5th grade elementary school students with reading disabilities. International Psycho- Educational Research Reviews, 4(2), 39-45.

Peterson-Karlan, G. R., \& Parette, H. P. (2007). Evidence-based practice and the consideration of assistive technology. Assistive Technology Outcomes and Benefits, 4(1), 130-139.

Saba, M.S. (2013). Writing in a new environment: Saudi ESL students learning academic writing [Doctoral dissertation, the Virginia Polytechnic Institute and State University]. Retrieved December 27, 2020, from https://vtechworks.lib.vt.edu/bitstream/handle/10919/54012/

Saba_MS_D_2014.pdf?sequence=1\&isAllowed=y

Santangelo, T., Harris, K., \& Graham, S. (2016). Self-regulation and writing: Metaanalysis of the self-regulation processes in Zimmerman and Risemberg's model. In C. MacArthur, S. Graham, \& J. Fitzgerald (Eds.), Handbook of writing research (pp. 174193). The Guilford Press.

Sari,Y. Sumar,M, UtomoD.\& Astina,I(2021). The effect of problem based learning on problem solving and scientific writing skills. International Journal of Instruction, 14(2), 11-26.

Sean, J., Lowrey, K., Bruce, A. \& Rowland, F.(2020). Effective technology supported writing strategies for learners with disabilities. Inclusion, 8(1), 58-73.

Shaw, D.L. (2010). Bridging differences: Saudi Arabian students reflect on their educational experiences and share success strategies [Doctoral dissertation, Oregon State University]. Retrieved December 27, 2020, from https://ir.library.oregonstate.edu/concern/graduate_thesis_or_dissertations/9k41zk061 